\title{
A CD-Rom on Medicine in Literature
}

\section{Citation}

Browne, Janet. 2001. A CD-Rom on medicine in literature. Health Information and Libraries Journal 18: 156-158.

\section{Published Version}

http://dx.doi.org/10.1046/j.1471-1842.2001.00332.x

\section{Permanent link}

http://nrs.harvard.edu/urn-3:HUL.InstRepos:3363730

\section{Terms of Use}

This article was downloaded from Harvard University's DASH repository, and is made available under the terms and conditions applicable to Other Posted Material, as set forth at http:// nrs.harvard.edu/urn-3:HUL.InstRepos:dash.current.terms-of-use\#LAA

\section{Share Your Story}

The Harvard community has made this article openly available.

Please share how this access benefits you. Submit a story.

Accessibility 


\section{A CD-ROM on medicine in literature}

Janet Browne, Medical Historian (Life Sciences), Wellcome Trust Centre for the History of Medicine at UCL, 24 Eversholt Street, London NW1 1AD, UK

The Wellcome Trust through its Medicine, Society and History programme is sponsoring an exciting new project in the history of medicine that brings together several wings of the Trust's scholarly staff. The plan is to create a highly visual selfdirected learning module for medical students that will explain key concepts in the history of medicine by using examples drawn from English literature and literature in translation. George Eliot's Dr Lydgate will join Dr Zhivago, Sherlock Holmes and Dr Watson, Mr Rochester's mad wife in the attic and others from European, Russian, Indian and American literature, old and new, western and non-western, to provide a lively, richly illustrated and authoritative teaching product. The course will be supplied on CD-ROM suitable for loading onto an intranet, with future provision for online distribution, and is designed to fit into University College London's medical curriculum as a special study module. Written by historians at the new Centre for the History of Medicine at UCL, it will showcase the world-famous resources of the Wellcome Library for the History and Understanding of Medicine and draw extensively on a wide range of stunning images from the Iconographic collections, Medical Photographic Library and Medical Film and Video Library. Electronic experts from the Wellcome Trust's Tropical Medical Resource are masterminding design and production, using their experience from creating similar teaching resources on tropical diseases. The course will be ready for trials in 2001 and (with luck) released to students at the start of the academic year 2002. If successful, it is hoped to make it available to other bodies.

The impetus for this collaboration has come from the introduction of the new medical curriculum in London's medical schools, in keeping with recommendations from the General Medical Council. The curriculum provides several

Correspondence e-mail: j.browne@ucl.ac.uk opportunities for prospective doctors to broaden their education, especially in the humanities. These special study modules are, in part, intended to help students understand the diversity of backgrounds and the cultural variety of the patients they will eventually meet, as well as putting their own participation in modern medicine in a wider social context. It was thought that a short course on the relations between literature and medicine would usefully introduce a range of issues and approaches to the history of health and illness which would encourage the student to acquire a sense of the chronological development of medicine and build a basic framework into which modern medical science can fit. It aims to be as inclusive as possible, touching on nonwestern medical systems as well as gender, professionalization, war and social issues. There are ulterior motives too. Creative literature involves the personal, the intimate, feelings of pain and joy. While the course is necessarily selective, we hope it will stimulate medical students to think about their patients as people and of the health professional's place in a long, fascinating, constantly changing tradition.

It aims to supply six teaching sessions broadly covering themes such as Doctors and Nurses in Literature, Medicine in Shakespeare's Time, Diseases in Literature, Medicine and the Mind, Medical Utopias and Dystopias, and Medicine in Cultural Context. Each session will be prefaced by an introductory essay that sets out the theme. Summaries of the novels, and commentaries on the extracts are also included, although for reasons of space not in the examples below. Each extract will be illustrated with appropriate historical images, perhaps some snatches of film for the First World War poets, for example. Supporting materials will supply the authors' biographical details, a pictorial timeline, self-test questions, details of the texts and visual sources, further reading in the history of medicine, and so on. 


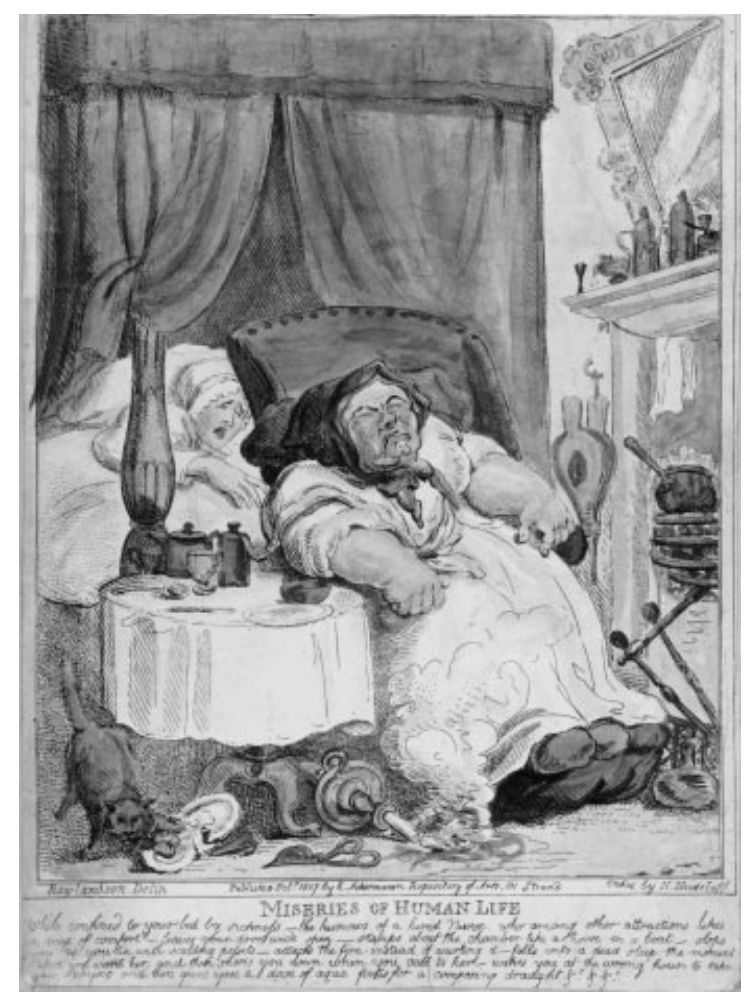

Figure $1 \mathrm{~A}$ convalescent woman trying in vain to rouse her hired nurse. Etching by Nicolaus I. W. C. von Heideloff, 1807, after Thomas Rowlandson

The two examples given below offer opportunities to explore perceptions of medicine, hospitals, monsters and madness in the nineteenth century via the literary extracts and the accompanying images. We can only produce a glimpse here of the kind of multimedia resource that will eventually be produced, but it is hoped that it will at least convey a flavour of what should prove to be an innovative new learning aid.

\section{Martin Chuzzlewit by Charles Dickens, London 1844}

'She was a fat old woman, this Mrs Gamp (Fig. 1), with a husky voice and a moist eye, which she had a remarkable power of turning up, and only showing the white of. Having very little neck, it cost her some trouble to look over herself, if one may say so, at those to whom she talked. She wore a very rusty black gown, rather the worse for snuff, and a shawl and bonnet to correspond. In these dilapidated articles of dress she had, on principle,

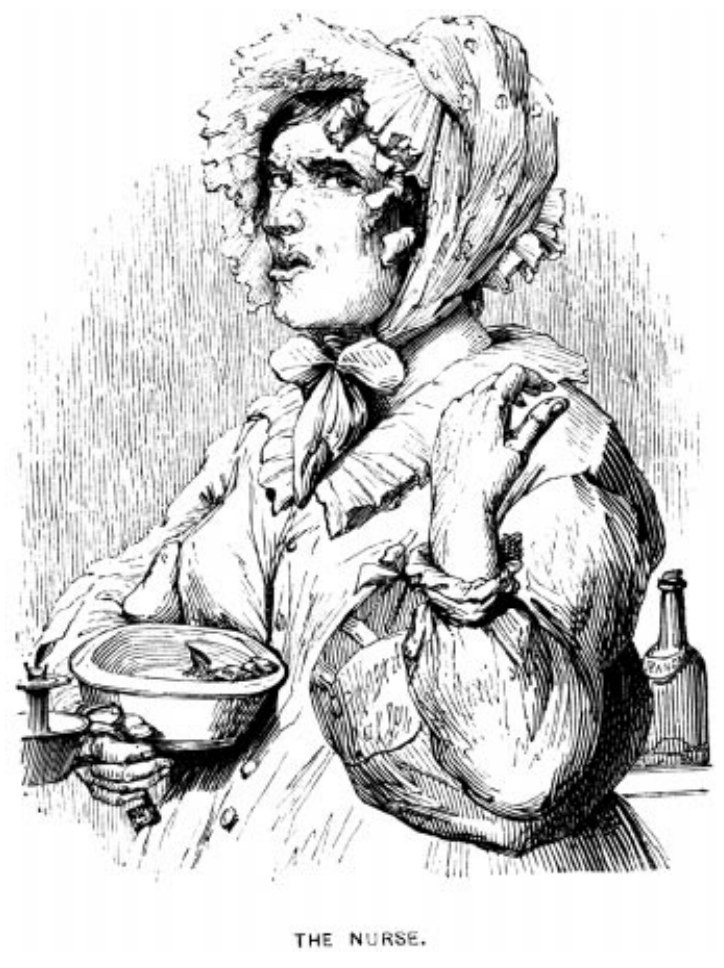

Figure 2 A caricature of a drunken nurse. Wood engraving, artist unknown. With a red nose and a hand that gestures towards an almost empty brandy bottle, it is clear that the only thing this mid. 19th century nurse cares for is a tipple

arrayed herself, time out of mind, on such occasions as the present; for they at once expressed a decent amount of veneration for the deceased, and invited the next of kin to present her with a fresher suit of weeds: an appeal so frequently successful, that the very fetch and ghost of Mrs Gamp, bonnet and all, might be seen hanging up, any hour in the day, in at least a dozen of the second-hand clothes shops about Holborn. The face of Mrs Gamp - the nose in particular - was somewhat red and swollen, and it was difficult to enjoy her society without becoming conscious of a smell of spirits (Fig. 2). Like most persons who have attained to great eminence in their profession, she took to hers very kindly; insomuch, that setting aside her natural predilections as a woman, she went to a lying-in or a lying-out with zest and relish.

"Ah!" repeated Mrs Gamp; for it was always a safe sentiment in cases of mourning. "Ah dear! When Gamp was summonsed to his long home, and I see him a lying in Guy's Hospital with a 


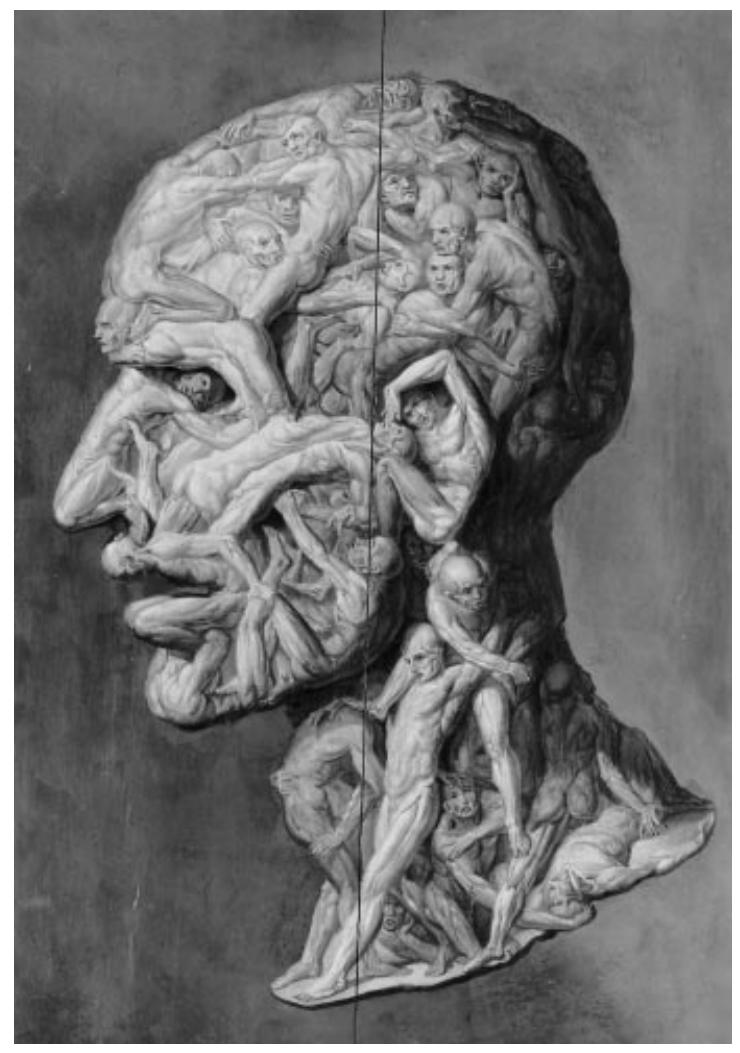

Figure 3 Head of a man, composed of nude figures. Oil painting, artist unknown. An image that vividly presents 19th century notions of the conflicting emotions that coexist in the human mind

penny-piece on each eye, and his wooden leg under his left arm, I thought I should have fainted away. But I bore up".'

\section{The Strange Case of Dr Jekyll and Mr Hyde by Robert Louis Stevenson, Edinburgh 1886}

'Now, the hand of Henry Jekyll (as you have often remarked) was professional in shape and size; it was large, firm, white and comely. But the hand which I now saw, clearly enough in the yellow light of a mid-London morning, lying half shut on the bed-clothes, was lean, corded, knuckly, of a dusky pallor, and thickly shaded with a swart

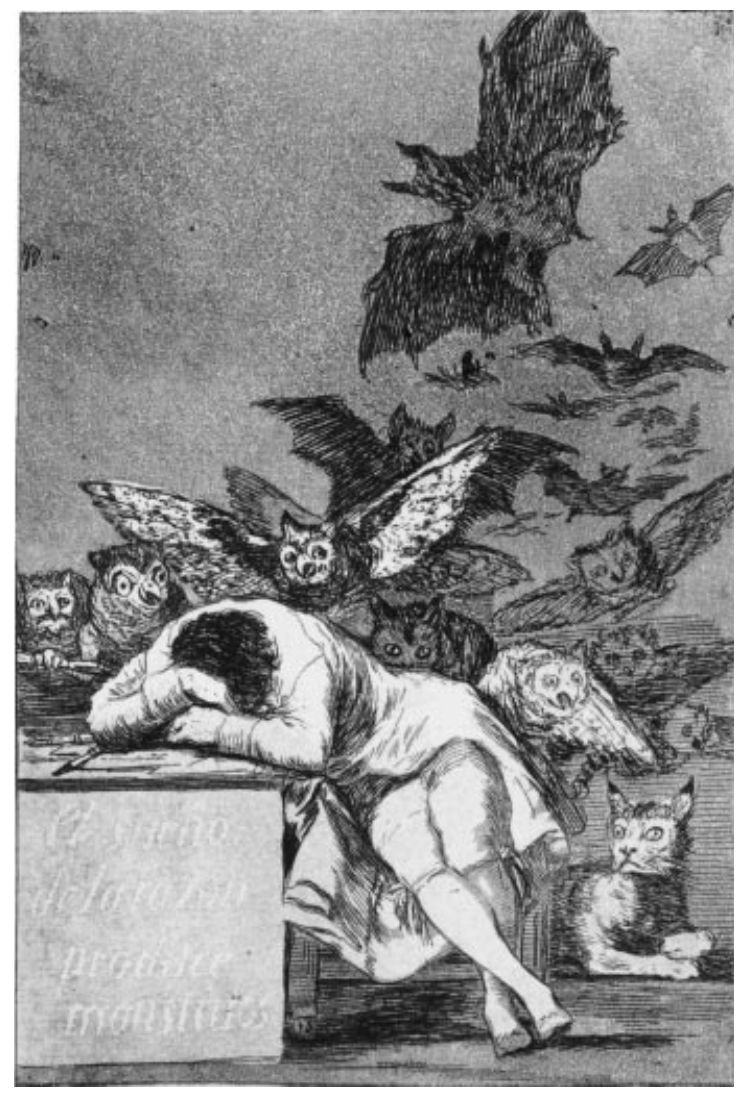

Figure 4 A man asleep dreaming of monsters. Etching by Fransisco Goya, 1796/98. In English, the caption reads, 'The sleep of reason induces monstrous thoughts'. This ghoulish scene bears witness to the concept that the monster we fear is in fact the externalization of the monster from within. Stevenson said that The Strange Case of Dr Jekyll and Mr Hyde was conceived after a nightmare

growth of hair. It was the hand of Edward Hyde (Fig. 3).

I must have stared upon it for near half a minute, sunk as I was in the mere stupidity of wonder, before terror woke up in my breast as sudden and startling as the crash of cymbals; and bounding from my bed, I rushed to the mirror (Fig. 4). At the sight that met my eyes, my blood was changed into something exquisitely thin and icy. Yes, I had gone to bed Henry Jekyll, I had awakened Edward Hyde.' 